\title{
A Comparative Study On The Hymenopteran Diversity With Special Reference To Ants In Thommankuth Forest And Adjacent Areas Of Idukki District In Western Ghats.
}

\author{
Bany Joy ${ }^{1}$ Gigi K Joseph ${ }^{2}$ \\ Department of zoology, Nirmala College, muvattupuzha, kerala, india.
}

\begin{abstract}
A comparative study on the hymenopteran diversity with special reference to ants in Thommankuth forest and adjacent areas was carried out for a period of six months from December 2014 to May 2015. The study held in Thommankuth forest and adjacent areas resulted in identifying 19 ant species. They belonged to one family named Formicidae and four subfamilies such as Formicinae, Myrmicinae, Ponerinae and Dolichoridinae. Out of the total 19 species observed, three species found only in forested areas, whereas four species found only in agricultural area. However 11 species were observed from both the habitats. According to Shannon Weiner diversity index agricultural ecosystem is more diverse (1.04412) than forest ecosystem (1.02115). The study reveals that Thommankuth forest and adjacent areas in the Western Ghats is an excellent habitat for Hymenopteran especially ants.
\end{abstract}

Keywords: Ants, thommankuth forest, agricultural area.western ghats.

\section{Introduction}

Insects are virtually everywhere on the Earth's surface; excluded only the extremes of climate at the poles and on the peaks of highest mountains; just a few species live in the sea. (Cheng, 1976).They have a strong hold in most ecosystem processes as they are pollinators and nutrient cyclers. A large number of them act on insect predators, and mutualists of all of which require conservation. Using insects how to study how creation of mosaics, fragmentation of land, deforestation and creation of monocultures have an impact on diversity and stability of an ecosystem is a challenging and interesting task as it not only involves the taxonomy of concerned group but is also related to the behavioural aspects of the taxa under study. They have lived on Earth about 300 million years compared with less than 1 million for man and during this time they have evolved in many direction to become adapted for life in almost every type of habitat. (Borror, 1964).Hymenoptera is a large order comprising of great many insects which are beneficial to man. Ants shows tremendous diversity,numerical and biomass dominance in almost every habitat throughout the world (Fittkau and Klinge,1973).It has been estimated by E.O.Wilson (1971) that the total number of individual ants alive in the world at any one time is between one and ten quadrillion(short scale).According to this estimate, the total biomass of all the ants in the world is approximately equal to the total biomass of the entire human race (Wilson.1971).Most of the ants have either a direct or indirect relationship with vegetation. Some of these are highly specific to the habitat in which they occur, depending on the maximum benefits they attain for the nesting, mating and food availability. Their preference of microhabitat due to the above mentioned criteria were investigated by sampling ant fauna in various habitats (Viswanathan et.al, 2000).

The objectives of the study are, to investigate the diversity of Hymenopterans (Formicidae) in the Thommankuth forest in Kaliyar Range,to assess the habitat preference of ant species in different vegetation types of agricultural and forest ecosystems,to assess to distribution and abundance of ants in forest and agricultural ecosystems. Thommankuth forest area belongs to Kothamangalam Forest division and located in Thodupuzha Taluk in Idukki district is one of the major ecotourism centers in Kerala. The forest area is at 360 hectare and the vegetations are semievergreen forest, reverine ecosystem and Rock ecosystem. Thommankuth is a scenic waterfall in the Southern State of Kerala and an important low altitude forest of Western Ghats. It is situated between $9^{\circ} 57.243^{\prime}$ North latitude and $76^{\circ} 50.150^{\prime}$ East longitude and at an elevation of $65 \mathrm{~nm}$. The Western Ghats, one of the 34-biodiversity hotspots of the world (Myers et al, 2000) covering 5\% of India's land area. Landscape heterogeneity is abundant in the Ghats (Subhashchandran 1997, Ramachandra et al., 2007).

The Ghats support a variety of endemic flora and fauna because of the diverse habitats, which have got created due to the varying topography and climate (Menon and Bawa 1997). High species diversity and endemism is associated with the Western Ghats. (Daniels (1997)). The major flora in Thommankuth forest are Tectona grandis,Terminalia tementosa, Bambusa arundinaria, Terminalia myriocarpa, Polialthiyas etc.Agricultural area considered for the study was in Karimanoor Panchayat in Idukki district. Thommankuth forest area is $14 \mathrm{~km}$ away from the agricultural vegetations under study. The agricultural area is situated in an elevation of $60 \mathrm{~m}$ and $9^{\circ} 54^{\prime} 0^{\prime \prime} \mathrm{N}$ latitude and $76^{\circ} 47^{\prime} 0^{\prime \prime} \mathrm{E}$ longitude. The agricultural vegetations are banana 
plantation, rubber plantation and pineapple plantation. The major type of cultivation in Karimanoor Panchayath is rubber. A notable feature of Karimanoor Panchayath is that one side of the area is of forest and the other side is of agricultural area.

\section{Materials And Methods}

During study ants were collected from different habitats such as semi evergreen areas, rocky area and riverine areas in Thommankuth forest.Specimens were also collected from different type of agricultural plantation in Karimanoor namely: pineapple, rubber, and banana plantation. The specimens were collected from the following three methods.

\section{Pitfall trap}

Pitfall trap is for trapping ants. The effectiveness of sampling ants may vary from species to species depending on their activities, and properties of the ground layer. Dung baited pitfall traps were used. The trap consisted of plastic cups placed at ground level (diameter $14 \mathrm{~cm}$ and height $10 \mathrm{~cm}$ ) each jar contains $4 \%$ formalin. They were placed at randomly selected areas. Insects trapped in the jars were sorted and preserved in labeled containers of $70 \%$ alcohol. The insects were then mounted after the technique of Bolton (1994).

\section{Quadrate method}

Formicidans belonging to different families were collected by using quadrate method. 28 quadrates of 10 x 10m size were selected from four different vegetations. Vegetations selected were Rubber plantation (13 Quadrates), Banana plantation (5 Quadrates), pineapple plantation (5 Quadrates) and Coffee plantation (5 Quadrates). 30 minutes were spent in each quadrate. Hymenopterans were caught using insect collecting net. Specimens were put into labelled bottles containing benzene.

\section{Opportunistic method}

Opportunistic method was also used for the study. Irrespective of the scheduled time, ant specimen were collected from whenever and wherever possible during the study period from different habitats of the study area. Specimens collected from all traps were sorted, cleaned and preserved in 70\% ethyl alcohol. The vials were labeled with the place, date of collection. Collected species were identified using standard identification manuals by using identification keys in Bingham (1975) Bolton (1994) and also some specimens were sent to specialist to confirm their identity. A reference collection is maintained in the Museum of St.Xaviers College for Women, Aluva. From the data obtained, The rank abundance of the species were described using graphical method and statistical analysis was carried out using diversity index. The species diversity was calculated using Shannon - Weiner index for both agricultural and forest ecosystem. Shannon-Weiner index is based on the weighted geometric mean of the proportional abundance of the different species. Shannon-Weiner index $H^{\prime}=-$ $\sum \mathrm{Pi} \ln \mathrm{Pi}$

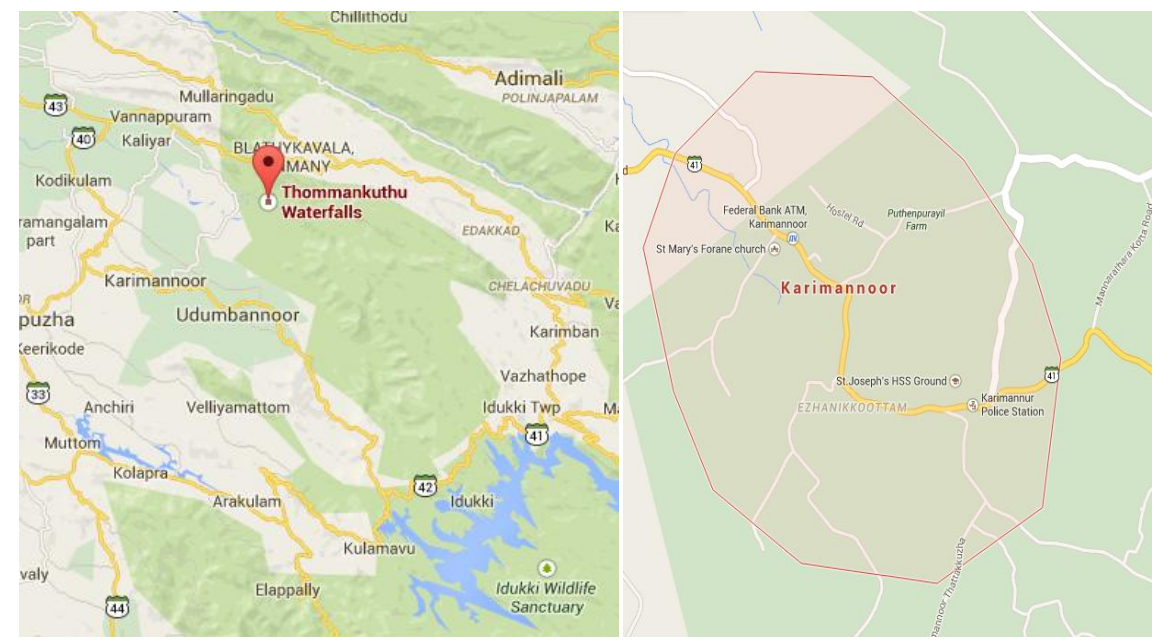

Fig 1: Map showing Thommankuthu forest

Fig 2: Map showing Karimanoor 


\section{Different Vegetations Selected For The Study \\ Forest ecosystem}

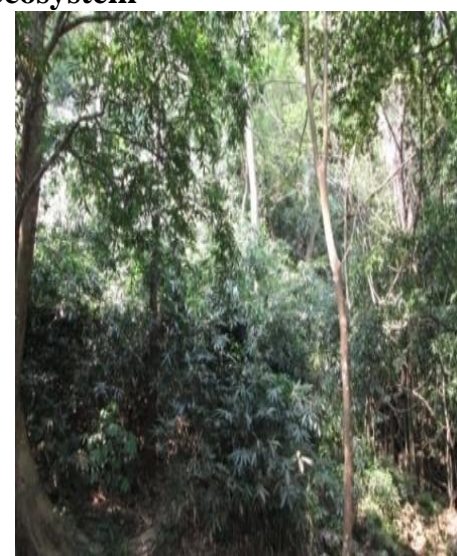

Fig 3: Semi evergreen forest

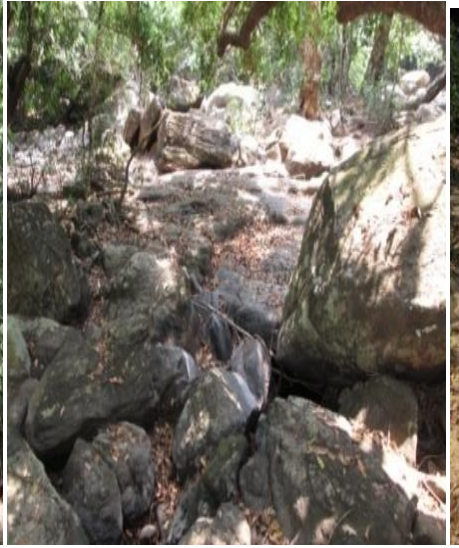

Fig 4: Rock ecosystem

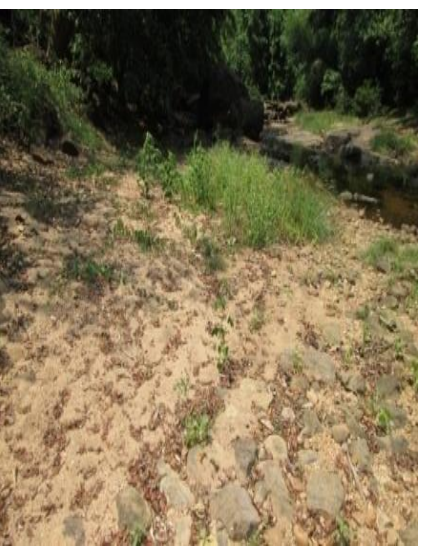

Fig 5:Riverine

\section{Agricultural ecosystem}

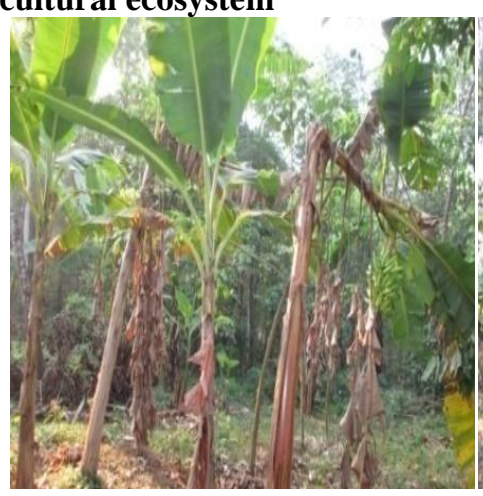

Fig 6: Banana plantation

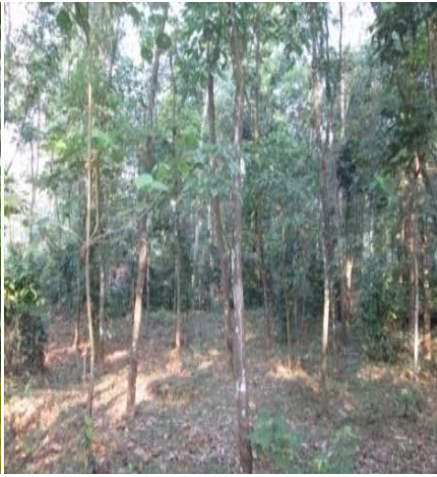

Fig 7: Rubber plantation

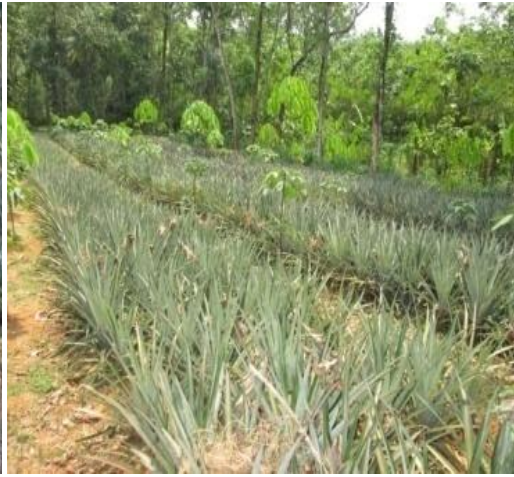

Fig 8: Pineapple plantation

\section{Result And Discussion}

\section{Overall ant diversity}

Through the study of ant fauna of Thommankuth forest and the agricultural area, a total of 19 type specimen were observed from thommankuth forest and adjacent areas.All of them belongs to the family Formicidae (table 1).

Table 1: Checklist of Ants(Hymenoptera: Formicidae) collected form Thommankuth forest and agricultural

\begin{tabular}{|l|l|l|l|l|}
\hline Sl.No & Family & Subfamily & Genus & Species \\
\hline 1 & Formicidae & Formicinae & Componotus & Angusticollis, Jerdon \\
\hline 2 & Formicidae & Formicinae & Componotus & carin carin, Emery \\
\hline 3 & Formicidae & Formicinae & Componotus & Compressus, Fabricius \\
\hline 4 & Formicidae & Formicinae & Componotus & mitis ,Smith \\
\hline 5 & Formicidae & Formicinae & Componotus & parius, Emery \\
\hline 6 & Formicidae & Formicinae & Componotus & Rufoglaucus, Jerdon \\
\hline 7 & Formicidae & Formicinae & Leptogenys & dentilobis ,Forel \\
\hline 8 & Formicidae & Formicinae & Oecophylla & Smaragaina,Fabricius \\
\hline 9 & Formicidae & Formicinae & Paratrechina & longicornis,Latreille \\
\hline 10 & Formicidae & Formicinae & Polyrhachis & rastellata, Emery \\
\hline 11 & Formicidae & Formicinae & Polyrhachis & tibialis, Smith \\
\hline 12 & Formicidae & Myrmicinae & Monomorium & phanaonis, Linnaeus \\
\hline 13 & Formicidae & Myrmicinae & Meranoplus & biclor, Guerin \\
\hline 14 & Formicidae & Myrmicinae & Myrmicaria & brunnea, Saunders \\
\hline 15 & Formicidae & Myrmicinae & Solenopsis & Geminate,Fabricius \\
\hline 16 & Formicidae & Ponerinae & Diacamma & assamense, Forel \\
\hline $\mathbf{1 7}$ & Formicidae & Ponerinae & Diacamma & sculptum, Jerdon \\
\hline 18 & Formicidae & Ponerinae & Odontomachus & haematodus, Linnaeus \\
\hline 19 & Formicidae & Dolichoderinae & Technomyrmex & albipes, Smith \\
\hline
\end{tabular}




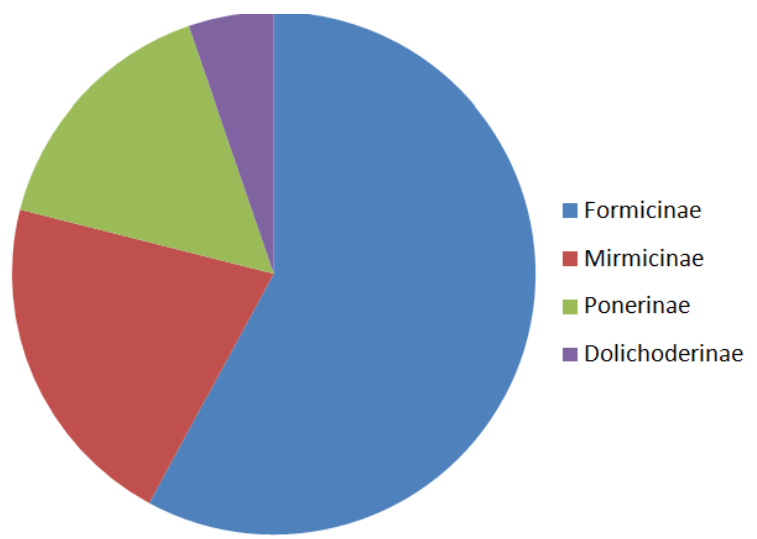

Fig 9: Subfamily wise distribution of ants collected during the study.

Ant species richness increases with increase in vegetation and vice versa (Sunil et.al 1997). Similar findings have been reported in this study which took place in forest ecosystem too with semievergreen forest type with high richness and the rock ecosystem with low richness. And in agricultural ecosystem plantain vegetation shows high species richnes. These results concordant with several studies in other parts of Western Ghats. (Anu and Sabu, 2007).

\section{Habitat preferences of ants in forest ecosystem}

Table 7: Checklist of ants in different habitats of forest ecosystem.

\begin{tabular}{|l|l|l|l|l|}
\hline Sl.No & Species name & Semievergreen forest & Reverine & Rock \\
\hline 1. & Paratrachena longicornis & 26 & - & - \\
\hline 2. & Diacemma assamense & 18 & - & - \\
\hline 3. & Componatus parius & 32 & - & 16 \\
\hline 4. & Meraroplus bicolor & 21 & - & - \\
\hline 5. & Componotus augusticolis & 31 & - & 21 \\
\hline 6. & Technomyrmex albipes & - & 68 & - \\
\hline 7. & Polyrhachis tibialis & 148 & - & - \\
\hline 8. & Myrmicaria brunnae & 63 & - & - \\
\hline 9. & Polyrhachis rastellata & 28 & - & - \\
\hline 10. & Diacamma sculptum & 31 & - & - \\
\hline 11. & Odontomachus haematodus & 38 & - & - \\
\hline 12. & Solenopsis geminata & 64 & - & - \\
\hline 13. & Oecophylla smaragdina & 176 & - & 116 \\
\hline 14. & Componotus rufoglaucus & 39 & - & - \\
\hline 15. & Leptogenys dentilobis & 39 & & - \\
\hline
\end{tabular}

Distribution and abundance of Formicidae in forest ecosystem is mentionaed in the table 7.

\section{Status of ants in thommankuth forest and adjacent areas}

.Table 9: Checklist of ants in different vegetation types of Thommankuth forest and agricultural ecosystem

\begin{tabular}{|c|c|c|c|c|c|c|c|}
\hline Sl.No & Species name & Rubber & Pineapple & Plantain & $\begin{array}{l}\text { Semi } \\
\text { evergreen }\end{array}$ & Reverine & Rock \\
\hline 1. & Paratrachena longicornis & - & - & 9 & 26 & - & - \\
\hline 2. & Diacemma assamense & 13 & - & 11 & 18 & - & - \\
\hline 3. & Monomorium pharaonis & 48 & - & 63 & - & - & - \\
\hline 4. & Componatous parius & 9 & - & 21 & 32 & - & 16 \\
\hline 5. & Meranoplus bicolor & - & - & 13 & 21 & - & - \\
\hline 6. & Compontus augusticolis & - & - & - & 31 & - & 21 \\
\hline 7. & Technomyrmex albipes & 42 & - & 83 & - & 68 & - \\
\hline 8. & Polyrhachis tibialis & - & - & - & 148 & - & - \\
\hline 9. & Myrmicaria brunnae & - & - & 36 & 63 & - & - \\
\hline 10. & Componotus carin & 21 & - & 28 & - & - & - \\
\hline 11. & Polyrhachis rastellata & - & - & - & 28 & - & - \\
\hline 12. & Diacemma sculptum & 11 & 21 & - & 31 & - & - \\
\hline 13. & Odontomachus haematodus & 28 & - & 19 & 38 & - & 16 \\
\hline 14. & Solenopsis geminata & 46 & 26 & 73 & 64 & - & - \\
\hline 15. & Oecophylla smaragdina & 86 & 64 & 93 & 176 & - & 118 \\
\hline 16. & Componotus rufogloucus & - & - & 28 & 39 & - & - \\
\hline 17 & Componotus compressus & - & - & 28 & - & - & - \\
\hline 18. & Leptogenys dentilobis & - & - & 34 & 39 & - & - \\
\hline 19. & Componotus mitis & 28 & - & 26 & - & - & - \\
\hline
\end{tabular}




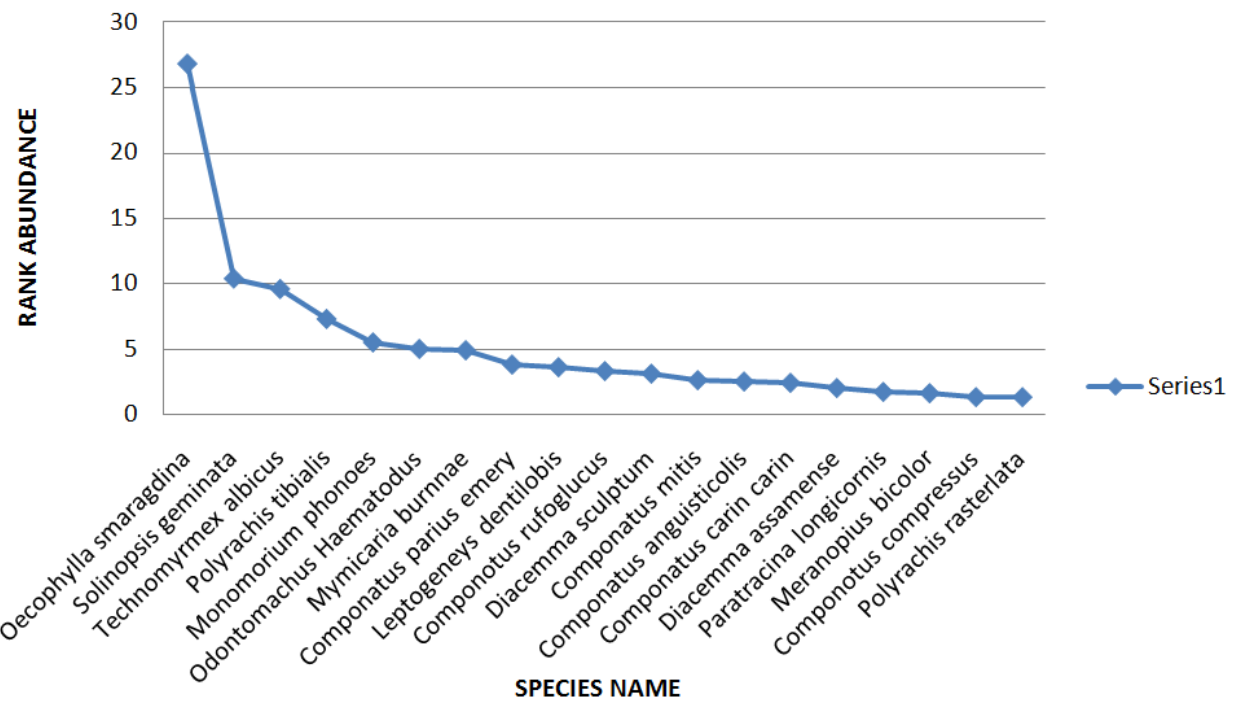

Fig 10: Rank abundance plot of ants collected from Thommankuth forest and agricultural ecosystem. Subfamily wise distribution of ants in different vegetation types

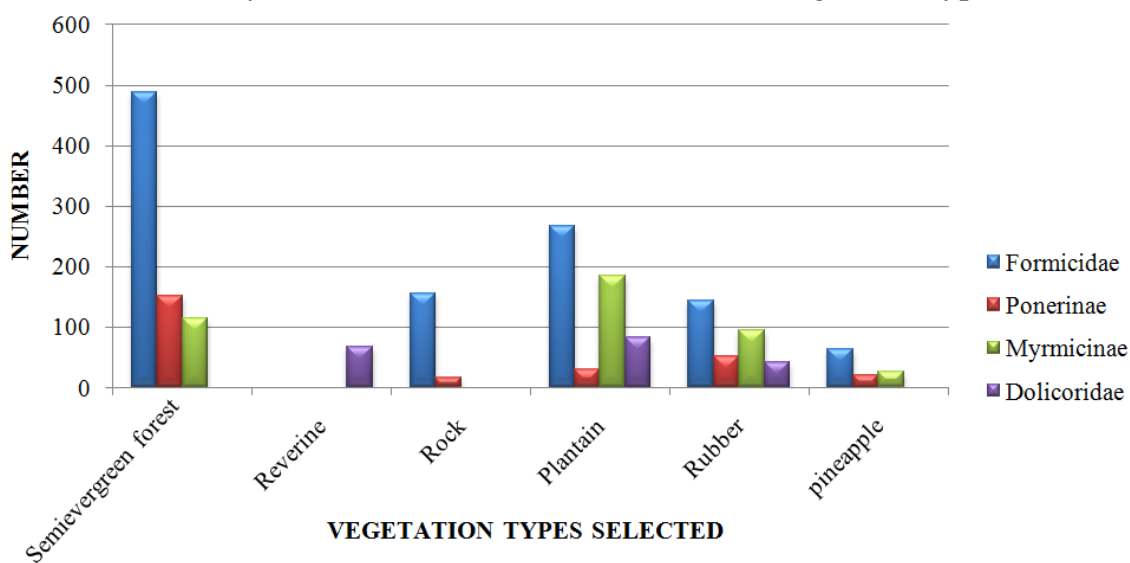

Fig 11: Graph showing the subfamily wise distribution of ants in different vegetation types

Subfamily Dolichoridae was considered to be highly dominant all over the world. But in this study it is only observed in the agricultural as well as forest ecosystem. Members of this subfamily acts as an excellent indicator species which determine human interference (Viswanathan \& Ajay, 2000.) presence of this species in the forest ecosystem indicates the human interference into the forest ecosystem.

\section{Diversity index}

According to Shannon weiner diversity index in forest ecosystem Solenopsis geminate with high diversity index and Diacemma assamense with least diversity index (table 10).The Shannon diversity index value of the 15 species collected from forest ecosystem are different. Paratrachena longicornis with -0.04142 , Componatus parius with -0.0636 , Myrmicaria brunnae with -0.07598 ect.. While analyzing the relative abundance Solenopsis geminate with high relative abandance and Diacemma assamense with least abundance.Variation is maximum between the different species for example Diacemma assamense with relative abundance 0.018126888 while in the case of Solenopsis geminate with 0.296072508 .Therefore the number of species also plays an important role in calculating Shannon Weiner diversity index, which is commonly used statistical method in calculating the diversity index of a particular region.

Table 10: Shannon - Weiner index of forest ecosystem

\begin{tabular}{|l|l|l|l|l|}
\hline Species & $\begin{array}{l}\text { Species } \\
\text { identification code }\end{array}$ & $\begin{array}{l}\text { Number of } \\
\text { individuals (n) }\end{array}$ & $\begin{array}{l}\text { Relative abundance } \\
(\mathrm{Pi})\end{array}$ & $\operatorname{lnPi}$ \\
\hline Paratrachena longicornis & 1 & 26 & 0.026183283 & -1.581975901 \\
\hline Diacemma assamense & 2 & 18 & 0.018126888 & -1.741676743 \\
\hline Componatus parius & 3 & 48 & 0.048338369 & -0.04142 \\
\hline Meranoplus bicolor & 4 & 21 & 0.021148036 & -1.315708011 \\
\hline Componotus augusticolis & 5 & 52 & 0.052366566 & -0.03157 \\
\hline Technomyrmex albipus & 6 & 68 & 0.06847936 & -1.280945905 \\
\hline
\end{tabular}


A Comparative Study On The Hymenopteran Diversity With Special Reference To Ants In.

\begin{tabular}{|c|c|c|c|c|c|}
\hline Polirhachis tibialis & 7 & 148 & 0.149043303 & -0.826687533 & -0.12321 \\
\hline Myrmicaria brunnae & 8 & 63 & 0.063444109 & -1.197608699 & -0.07598 \\
\hline Componotus rufoglocus & 9 & 28 & 0.028197382 & -1.549791217 & -0.0437 \\
\hline Polyrhachis rastellata & 10 & 31 & 0.03121853 & -1.505587555 & -0.047 \\
\hline Diacemma sculptum & 11 & 54 & 0.054380665 & -1.264555489 & -0.06877 \\
\hline Odontomachus haematodus & 12 & 64 & 0.064451158 & -1.190769275 & -0.07675 \\
\hline Solenopsis geminata & 13 & 294 & 0.296072508 & -0.528601918 & -0.1565 \\
\hline Oecophylla smaragdina & 14 & 39 & 0.039274924 & -1.405884641 & -0.05522 \\
\hline Leptogenys dentilobis & 15 & 39 & 0.039274924 & -1.405884641 & -0.05522 \\
\hline \multicolumn{6}{|l|}{ Total number of capture } \\
\hline Shannon Weiner index & & & & & 1.02115 \\
\hline
\end{tabular}

According to Shannon weiner diversity index in forest ecosystem Oecophylla smaragdina

with high diversity index and Paratrachena longicornis with least diversity index (table 11).The Shannon diversity index value of the 16 species collected from forest ecosystem are different. Paratrachena longicornis with -0.0183 , Componatus parius with ,- -0.04543 Myrmicaria brunnae with -0.05168 ect.. While analyzing the relative abundance Oecophylla smaragdina with high relative abandance and Paratrachena longicornis with least abundance

Table 11: Shannon - Weiner index of agricultural ecosystem

\begin{tabular}{|l|l|l|l|l|l|}
\hline Species & $\begin{array}{l}\text { Species } \\
\text { identification code }\end{array}$ & $\begin{array}{l}\text { number of } \\
\text { individuals (n) }\end{array}$ & $\begin{array}{l}\text { relative abundance } \\
(\mathrm{Pi})\end{array}$ & $\mathbf{l n P i}$ & $\mathrm{Pi}(\mathrm{lnPi})$ \\
\hline $\begin{array}{l}\text { Paratrachena } \\
\text { longicornis }\end{array}$ & 1 & 9 & 0.008928571 & -2.049218023 & -0.0183 \\
\hline Diacemma assamense & 2 & 24 & 0.023809524 & -1.62324929 & -0.03865 \\
\hline Monomorium phoenois & 3 & 111 & 0.110119048 & -0.958137553 & -0.10551 \\
\hline $\begin{array}{l}\text { Componatus parius } \\
\text { emery }\end{array}$ & 4 & 30 & 0.029761905 & -1.526339277 & -0.04543 \\
\hline Meranoplus bicolor & 5 & 13 & 0.012896825 & -1.88951718 & -0.02437 \\
\hline Technomyrmex albipes & 6 & 125 & 0.124007937 & -0.906550519 & -0.11242 \\
\hline Myrmicarea brunnae & 7 & 36 & 0.035714286 & -1.447158031 & -0.05168 \\
\hline $\begin{array}{l}\text { Componatus carin } \\
\text { carin }\end{array}$ & 8 & 49 & 0.048611111 & -1.313264452 & -0.06384 \\
\hline Diacamma sculptum & 9 & 32 & 0.031746032 & -1.498310554 & -0.04757 \\
\hline $\begin{array}{l}\text { Odontomachus } \\
\text { haematodus }\end{array}$ & 10 & 47 & 0.046626984 & -1.331362674 & -0.06208 \\
\hline Solenopsis geminata & 11 & 145 & 0.143849206 & -0.84209253 & -0.12113 \\
\hline Oecophylla smaragdina & 12 & 243 & 0.241071429 & -0.617854259 & -0.14895 \\
\hline $\begin{array}{l}\text { Componatus } \\
\text { rufoglucus }\end{array}$ & 13 & 28 & 0.027777778 & -1.556302501 & -0.04323 \\
\hline $\begin{array}{l}\text { Componatus } \\
\text { compresses }\end{array}$ & 14 & 28 & 0.0277777778 & -1.556302501 & -0.04323 \\
\hline leptogenys dentilobis & 15 & 34 & 0.033730159 & -1.471981615 & -0.04965 \\
\hline Componatus mitis & 16 & 54 & 0.053571429 & -1.271066772 & -0.06809 \\
\hline Total number of captures & & & & & 1.04412 \\
\hline Shannon Weiner index & & & & & \\
\hline
\end{tabular}

The data obtained by analyzing the Shannon weiner index of the given data, the following conclusions are obtained.the shannon weiner diversity index of agricultural ecosystem is 1.04412 and that of forest ecosystem is 1.02115.This values shows that the more diversity and abundance and distribution of species is observed in the agricultural ecosystem than that of forest ecosystem. The number of individuals also plays an important role in calculating Shannon weiner diversity index.

\section{Conclusion}

Species composition and diversity patterns in forest and agricultural ecosystems have been analyzed in this study. This study revealed that the dominancy exhibited by the Formicinae subfamily in agricultural as well as in forest ecosystem is due to their ability to adapt with different niches with a variety of feeding habits. The study held in Thommankuth forest and adjacent areas resulted in identifying 19 ant species. They belonged to one family named Formicidae and four subfamily such as Formicinae,Myrmicinae,Ponerinae and Dolichoridinae.Out of the total 19 species observed,three species found only in forested areas, whereas four species found only in agricultural area.However 11 species were observed in both the habitats. Technomyrmex albipes commonly found in human dominated,disturbed habitats,found also in thommankuth forest indicating growing disturbance happening to prestine forests. It may be due to the over interference of tourist into the forest as part of ecotourism without proper screening.Oeocophylla smaragdina was found as the most dominant 
ant species distributed in all habitats except the riverine area.According to Shannon Weiner diversity index agricultural ecosystem more diverse (1.04412) than forest ecosystem (1.02115).

\section{Recommendation}

The authorities should take proper measures to maintain the quality of forest.The study reveals that Thommankuth forest and adjacent areas is an excellent habitat for Hymenopteran especially ants.But long term studies strongly suggested to reveal a clear picture of ant diversity of Thommankuth forest in Western Ghats..

\section{Reference}

[1]. Agosti, D.L.E. and Schuts, T.R. 2000. Ants-standard method for measuring and monitoring Biodiversity.Smithsonian Institution Press. Washington DC.

[2]. Ali, T.M. 1991. Ant fauna of Karnataka - 1. Newsletter of IUSSI Indian Chapter 5: 2-8.

[3]. Ali, T.M. 1992. Ant fauna of Karnataka - 1. Newsletter of IUSSI Indian Chapter 6: 1-9.

[4]. Anderson,A.N. 1997.Ants as indicators of ecosystem restoration following mining :a functional group approach.Centre for conservation biology, The university of Queensland. Hymenoptera:Formicidae)at Forest Research Institute (FRI) Dehradun (India)

[5]. Anu, A. and Sabu,T . K. 2006. Biodiversity analysis of forest litter ant assemblage in the Wayanad region of Western ghats using taxonomic and conventional diversity measures. 13pp. Journal of Insect Science 7.06.

[6]. Beattie A.J. and Culver D.C.(1988). "Directed dispersal: demographic analysis of an ant-seed mutualism". American Naturalist 131

[7]. Bestelmeyer, B.T., and Wiens, J.A. 1996. The effects of land use on the structure of ground-foraging ant communities in the Argentine chaco. Ecological Applications 6: 1225-1240.

[8]. Bharti, H. 2002. List of Formicids research 26(4):337-342

[9]. Bingham , C .T .1903.Ants and Cockoo Wasps, The fauna of British India, including Ceylon and Burma :Hymenoptera, vol 2.London bioindicators in relation to fire management of spotted gum (Eucalyptus macualata

[10]. Bolton, B .1995.A new general catalogue of ants of the world. Harward University Press :London

[11]. Borror ,D.J.and Delong,D.M.1964.An introduction to study of insects. Holt, Rinehart and Winston ,inc:London

[12]. Chapman, J. W. \& Capco, S. R. 1951 . Check List of the Ants Hymenoptera : Formicidae) of Asia. Monogr. Inst. Sci. Tech.Manila, $1: 1-327,1$ map.

[13]. Cheng L (ed). 1976. Marine Insects, North Holland, Amsterdam.

[14]. Chhotani, O.B.and Marti, P.K. 1977Contribution to the Knowledge of Formicidae of the Andaman islands. News letter of Zoological suevey of India:3(1):17-20

[15]. Collingwood, C. A. 1970. Formicidae (Hymenoptera : Aculeata) from Nepal. Khumbu HimaL, Universitatsverlag Wagner, Innsbruck-Munchen,

[16]. Creighton W.S.,1950.The ants of North America.Bulletin of the museum of comparative zoology,Harward.

[17]. Daniels, R.J. 1997. Taxonomic uncertainities and conservation assessment. Current Science. 73 (2): 169 - 172

[18]. Deyrup,M.L.,.Davis, L. and Cover, S.1989.Exotic ants of Florida.Transactions of the American entomological society.

[19]. Dumpert ,K). 1978. The Social Biology of Ants

[20]. Evans ,W.C. and Leston, D .1971. Bull. Entomol. Res. 61: 357-362.

[21]. Fellers, J.H. 1987. Interference and exploitation in a guild of woodland ants. Ecology 68: 1466-1478.

[22]. Fisher, B.L.and Robertson, H.2002.Comparison and origin of forest and grassland ant assemblages in the high plateau of Madagascar biotropica. Current Science. 73: $134-136$

[23]. Fittkau, E.J. and Klinge,H. 1973. On biomass and trophic structure of the Central Amazonian rain forest ecosystem. Biotropica 5: 214.. Current Science. 73

[24]. Greenslade P.J.M.,1980.Ants(Hymenoptera;Formicidae) of Tasmania rain forest,Report to department of parks and wildlife heritage.Tasmania,Australia.

[25]. Hickman J.C.1974.Pollination by ants;a low energy system.Science 184

[26]. Holldobler,B. AND Wilson ,E.O.1990.The Ants .The Belknap Press of Harward University ,Cambridge,

[27]. Massachusetts Hook 1997 forests in South East Queensland. Memoirs of the museum of Victoria,

[28]. Janzen, D.H.1966.,Coevolution and mutualism between ants and acacias in central America.Evolution 20.

[29]. Karmaly ,K.A.., Narendran, T.C.2006.Indian Ants Genus Camponotus Mayr.Terresian Karmal Publication.kerala

[30]. Lubbock, J.,1881. Observations on ants, bees, and wasps,color of flowers as an attraction to bees; experiments and considerations thereon.J.Linn.Lond.(Zool).

[31]. Lyford, W.H.,1963.Importence of ants to brown podzolic soil genesis in new England.Harward forest paper no.7.Petersham.

[32]. Lynch, J. F., Johnson, A. K. and Balinsky, E. C. 1988. Spatial and temporal variation in the abundance and diversity of ants (Hymenoptera: Formicidae) in the soil and litter layers of a Maryland forest. Am. Mid. Nat. 119: 31-44

[33]. Macmohan J.A.,Mull J.F.and,Crist T.O.,2000.Harvester ants (Pogonomyrmex species.) their community and ecosystem influences.Annual review of ecology and systematic 31.

[34]. Major, J. D. 1985. Recolonization by ants of rehabilitated mineral sand mines on North Stradbroke Is. Queensland, with particular reference to seed removal. Aust. J. Ecol. 10: 31-48

[35]. McKenzie, D.H., Hyatt, D.E. and McDonald, V.J. editors.1995. Ecological indicators. Chapman and Hall, London, England

[36]. Menon S and Bawa. K.S. 1997. Applications of geographic information systems, remote

[37]. methods for rapid assessment of biodiversity. Ecological Applications 6: 594-607.

[38]. Michener C.D.,2000.The bees of the world.Baltimore Johns Hopkins University Press.

[39]. Myers ,N ., Mittermrir,C.G. and Kent, J.2000 .Biodiversity hotspots for conservation priorities .Nature 403:820-828

[40]. Noss, R. F. 1990. Indicators for monitoring biodiversity: a hierarchical approach. Conserv. BioI. 4: 355-364

[41]. Oliver I and Beattie,A.J. 1996. Designing a cost effective invertebrate survey.

[42]. Ramachandran ,T.V. ., Subhash Chandra ,M.D . Joshy, N.V. ,Narendra ,A.T. and Ali ,M .2012.Energy and Wetland research group centre for ecological science

[43]. Rastogi N,P.,Nair,Kolatkar M., William H. and Gdagkar. R.1997,Indian institute of science campus survey and some preliminary observations.J.Indian institute of science; 77.

[44]. Spellerberg. 1992. Evaluation and Assessment for Conservation. Chapman and Hall.

[45]. Stacy M. 2009. "Nest-site Limitation and Nesting Resources of Ants (Hymenoptera: Formicidae) in Urban Green Spaces" (PDF). Environmental Entomology 
[46]. Subhaschandran,M.D. 1997. On the Ecological history of Western Ghats. Current Science.

[47]. Tiwari,R.N. and Jonathan J.K. 1986 .A New species of Lyomyrmex Mayr from Andaman Nicobar islands (Hymenoptera:Formicidae)Records of Zoological survey of India

[48]. Vanderwoude C, Anderson, A.N .and Alan, P.N. 1997. Ant communities

[49]. Varghese T.2009. Ant fauna of Indian Institute Campus

[50]. Veeresh ,G.K. and Ali, T.M. 1991. The present status of our knowledge of Indian ants: 77-

[51]. Viswanathan and Narendra,2000.The effect of urbanization on the biodiversity of ants in Banglore .J.Ecobio;12

[52]. Wilson E. O. 1971. Insect Societies. Belknap Press, Cambridge, Massachusetts

[53]. Wood,J.G.,1994.Study of Insect Life volume 2.Arihant publishing house,Jaipur.

[54]. Yeatman, E. M., and. Greenslade. P.J.M 1980. Ants as indicators of habitat in three conservation parks in south Australia. South Aust. Nat. 55: 20-26.

[55]. Web references

[56]. www.wikipedia.com accessed on 24 February, 2015.

[57]. http://ces.iisc.ernet.in/Ant Taxonomi/index.htm accessed on 15 February, 2015. 